\title{
Penerapan Keselamatan dan Kesehatan Kerja pada Aktivitas Wisata Berenang Bersama Ikan Hiu (Swim with Shark) di Pulau Serangan, Denpasar Selatan
}

\author{
Julius Simon a, 1, Made Sukana a, 2
}

1julius_simon95@yahoo.com,2made_sukana@unud.ac.id

a Program Studi S1 Destinasi Pariwisata, Fakultas Pariwisata,Universitas Udayana, Jl. Dr. R. Goris, Denpasar, Bali 80232 Indonesia

\section{Abstract}

Selection of research is motivated by the increased interest of tourists will kind of attraction travel in Bali. In this kind of travel these attraction are extreme types of tourist activity in Pulau Serangan is, Swim with Sharks. Of course, by choosing the type of extreme travel to swim with the sharks, the great possibility of the risk of accidents caused. Hence the importance of this research study releated to health and safetyof employees and tourist who do this activity in Pulau Serangan.

The data used in this research is qualitative data, while the data source in the form of primary data and secondary data. Data was collected through observation, interviews, and library research. And assisted with the descriptive data analysis techniques.

In applying the safety and health at tourism activities swim with sharks, this report uses occupational safety and health procedures that apply to employees and tourist who do that tourism activity. Besides, the factors triggering the accident, or the result of the impact and the prevention and mitigation to be part of the discussion of this report. The results showed that the application of occupational safety and health on travel activity swim with sharks being the foremost, so most have applied, only need the addition of some other procedure for the safety of travelers.

\section{Keywords: Attraction Tourism, Swim With Shark, Occupational health and safety}

\section{PENDAHULUAN}

Bali merupakan suatu destinasi yang tingkat perkembangan sektor pariwisata nya lebih pesat dibandingkan dengan berbagai pulau lainnya yang ada di Indonesia, sehingga jumlah kunjungan wisatawan ke Bali dapat dikatakan semakin meningkat. Hal ini menjadi kesempatan bagi para pelaku usaha dalam mengembangkan bisnis dibidang pariwisata. Berbagai jenis atraksi wisata yang sederhana hingga yang ekstrim pun ditawarkan kepada wisatawan. Alhasil tidak sedikit pula atraksi tersebut menimbulkan berbagai resiko seperti kecelakaan dan lain sebagainya. Seringkali kecelakaan terjadi akibat kurang adanya pengawasan terhadap suatu aktivitas yang berlangsung. Pengawasan itu dapat berupa perhatian khusus terhadap keselamatan dan kesehatan kerja seseorang. Apabila kondisi seseorang dalam keadaan yang kurang fit ataupun kurang berhati-hati, hal ini dapat memicu terjadinya kecelakaan. Selain penyebab yang ditimbulkan dari dalam diri seseorang, penyebab lainnya juga dapat dipicu dari eksternal atau keadaan disekitar orang tersebut seperti alam lingkungan. Salah satu contohnya seperti di Pulau Serangan, Denpasar Selatan.

Ada beberapa jenis usaha pariwisata di Pulau Serangan yang melebarkan usahanya menjadi berbagai macam aktivitas wisata, misalnya seperti pada Restoran Gold Island Beach Club yang awalnya hanya mendirikan bisnis wisata kuliner, kini merambah pada jenis wisata ekstrim yang bernama swim with shark atau aktivitas wisata berenang bersama ikan hiu. Aktivitas wisata ekstrim yang satu ini merupakan kegiatan wisata yang dilakukan wisatawan yaitu berenang bersama ikan hiu pada penangkarannya ditengah laut. Aktivitas ini merupakan jenis kegiatan wisata yang tergolong baru dan khusus daerah Bali, hanya dapat ditemukan di Pulau Serangan. Hal ini terbilang cukup ekstrim karena objeknya adalah salah satu binatang laut buas yang ditakuti karena binatang tersebut berbahaya.

Penerapan prosedur standarisasi keselamatan dan kesehatan kerja baik pada wisatawan maupun pemandu wisata adalah menjadi suatu hal penting yang perlu diperhatikan agar tidak terjadinya kecelakaan. Hal ini diterapkan agar mengantisipasi insiden yang tidak diinginkan dan tidak pernah diduga sebelumnya, misalnya, ikan hiu yang menyerang salah satu wisatawan atau pemandu wisata secara tiba-tiba tanpa suatu alasan dan lain-lain. Faktanya, dilapangan tepatnya lokasi Pulau Serangan dengan aktivitas wisata berenang bersama ikan hiu (swim with shark) tersebut belum seutuhnya memiliki 
kelengkapan prosedur keselamatan dan kesehatan kerja dan surat-surat lainya terkait dengan keselamatan seseorang secara resmi. Kondisi seperti ini akan menimbulkan konflik bagi beberapa pihak serta jenis usaha tersebut apabila terjadi suatu insiden yang tidak pernah terduga ataupun yang tidak diingankan sebelumnya.

Oleh karena itu, pelaku usaha setidaknya perlu menerapkan prosedur standarisasi K3 pada usaha yang didirikannya sehingga dapat mengantisipasi kecelakaan di lapangan. Di sisi lain pihak wisatawan juga harus lebih cermat dalam memilih jenis kegiatan apa saja yang aman untuk dilakukan. Dengan demikian keselamatan dan kesehatan kerja karyawan maupun wisatawan tetap terjaga.

Adapun tujuan dari penelitian ini yaitu untuk dapat mengetahui aktivitas yang dilakukan wisatawan serta sejauh mana penerapan prosedur keselamatan dan kesehatan kerja yang sesuai pada aktivitas wisata berenang bersama ikan hiu (swim with shark) di Pulau Serangan.

\section{TINIAUAN PUSTAKA}

Telaah penelitian sebelumnya yang digunakan peneliti terhadap kesamaan fokus yakni penelitian yang dilakukan oleh Agastya (2014), menjelaskan bahwa pemilihan penelitian ini dilatarbelakangi karena pentingnya penerapan K3 pada atraksi wisata watersport. Telaah penelitian selanjutnya terletak pada kesamaan lokasi yang dilakukan oleh Sudiana menjelaskan bahwa satwa penyu harus tetap dilestarikan sebagai bagian dari budaya masyarakat desa Serangan. Penelitian ini menggunakan beberapa pedoman konsep untuk menganalisis data yang didapat di lapangan, yaitu: Konsep keselamatan dan kesehatan kerja (K3) (Sucipto (2014:2)), Konsep Penerepan atau "implementasi (Undang-Undang No 1 Tahun 1970), Konsep atraksi wisata (Damardjati (2003: 126)).

\section{METODE}

Penelitian ini dilakukan di kawasan penangkaran ikan hiu, Pulau Serangan, Kota Denpasar. Lokasi ini tepatnya berada di Jln. Tukad Punggawa No. 238x Dermaga Serangan, Denpasar - Bali. Adapun ruang lingkup yang membatasi penelitian ini yaitu:
1. Aktivitas yang dilakukan wisatawan pada wisata ekstrim berenang bersama ikan hiu (swim with shark).

2. Penerapan prosedur keselamatan dan kesehatan kerja pada aktivitas wisata berenang berama ikan hiu (swim with shark)

3. Faktor-faktor penyebab terjadinya kecelakaan pada aktivitas wisata berenang bersama ikan hiu (swim with shark).

4. Penerapan keselamatan dan kesehatan kerja pada karyawan/pemandu wisata berenang bersama ikan hiu (swim with shark) di Pulau Serangan.

5. Penerapan keselamatan dan kesehatan kerja pada wisatawan yang melakukan atraksi wisata berenang bersama ikan hiu (swim with shark) di Pulau Serangan.

Jenis dan sumber data dalam penelitian ini menggunakan jenis data kualitatif, seperti: hasil wawancara yang ditulis dengan deskriptif, sejarah dan gambaran umum lokasi penelitian, sedangkan sumber data yaitu sumber data primer serta sumber data sekunder (Arikunto 2010:22). Dalam pengumpulan data menggunakan tiga teknik, yaitu: Observasi, dimana teknik pengumpulan data berdasarkan pengamatan yang dilakukan peneliti terlebih dahulu sebelum melakukan penelitian, yang bertujuan agar mendapatkan gambaran yang jelas mengenai seberapa jauh penerapan keselamatan dan kesehatan kerja pada aktivitas wisata berenang bersama ikan hiu (swim with shark) oleh pengelola terhadap wisatawan di Pulau Serangan, Denpasar Selatan. Teknik wawancara menggunakan wawancara mendalam dengan mencari informasi mengenai apa saja aktivitas wisatawan dan sejauh mana penerapan K3 pada aktivitas wisata berenang bersama ikan hiu (swim with shark). Dokumentasi seperti gambaran umum catatan sejarah aktivitas wisata berenang bersama ikan hiu (swim with shark).

Dalam menentukan informan menggunakan teknik informan pangkal dalam penelitian ini adalah mereka yang mempunyai pengetahuan luas mengenai aktivitas berenang bersama ikan hiu (swim with shark) yang dilakukan oleh wisatawan yakni karyawan. Kemudian informan kunci yaitu mereka yang mengetahui dan memiliki berbagai informasi pokok yang diperlukan dalam penelitian yang disarankan oleh informan pangkal terkait dengan penerapan keselamatan dan kesehatan kerja 
pada wisatawan maupun karyawannya yakni Pihak Pengelola.

Teknik analisis data yang digunakan adalah teknik analisis data kualitatif dimana data yang telah diperoleh disusun secara sistematis dengan cara mengorganisasikan data ke dalam kategori, menjabarkan ke dalam unit-unit, melakukan sintesa, menyusun ke dalam pola, memilih mana yang penting dan yang akan dipelajari, dan membuat kesimpulan sehingga mudah di pahami (Sugiyono 2014: 244).

\section{HASIL DAN PEMBAHASAN}

Go Island Beach Club adalah sebuah restoran yang dibangun pada tahun 2014 dan terletak di Pulau Serangan. Perusahaan ini kemudian juga mendirikan jenis usaha aktivitas wisata berenang bersama ikan hiu (swim with shark). Sejak didirikannya aktivitas wisata ekstrim tersebut, pengelola perusahaan yang sebagian besar berasal dari nelayan itu mampu mendatangkan wisatawan domestik maupun asing sebagai penunjang aktivitas wisata swim with shark.

Pihak perusahaan mendirikan jenis usaha aktivitas wisata swim with shark didasari atas konsep ingin menjadikan ikan hiu sebagai daya tarik wisata yang berbasis pendidikan. Dimana wisatawan dapat berinteraksi lebih dekat dengan ikan hiu serta mempelajari siklus hidup daripada ikan tersebut. Selama didirikannya jenis kegiatan wisata ini, sebanyak 2.000 wisatawan sudah menyelam bersama ikan hiu dengan tanpa adanya kecelakaan ataupun keluhan dari pihak wisatawan karena memang dinilai cukup aman.

Jenis ikan hiu yang menjadi daya tarik wisata pada aktivitas berenang bersama ikan hiu (swim with shark) di Pulau Serangan adalah jenis ikan hiu sirip Putih (white tip). Pemilihan jenis ikan ini sebagai daya tarik wisata dikarenakan ikan tersebut merupakan ikan hiu karang yang hidupnya bergerombol. Ikan Hiu jenis ini tidak membahayakan manusia, karena makanannya adalah ikan-ikan kecil. Akan tetapi manusia harus tetap waspada terhadap ikan hiu, karena sewaktu-waktu ikan hiu juga bisa memangsa manusia dengan berbagai faktor yang terjadi.

Pemetakan kolam ikan hiu yang berada di tengah laut terdiri dari 2 keramba besar. Luas keramba tersebut masing-masing sebesar 98 meter persegi. Pengelompokan ikan hiu berdasarkan jenis ukurannya. Satu keramba terdapat 35 ikan hiu sedang yang dibagi menjadi 4 kolam, sedangkan satu keramba lainnya terdapat 10 ekor ikan hiu kecil beserta berbagai jenis ikan lainnya, seperti ikan cakala, ikan hias dan lainnya. Ukuran dari masingmasing ikan hiu beranekaragam mulai dari yang masih kecil $15 \mathrm{~cm}$ hingga ada juga ikan hiu sepanjang 1,5 - 2 meter. Apabila tidak dipisahkan anak ikan hiu akan langsung dimakan oleh ikan-ikan hiu besar lainnya.

\section{a. Aktivitas berenang bersama ikan hiu (swim with shark)}

Swim with shark jika diartikan dalam bahasa Indonesia yaitu berenang bersama ikan hiu. Dalam pengertian sederhananya adalah orang yang melakukan aktivitas renang bersama ikan hiu. Bagi sebagian orang pada umumnya berenang bersama ikan hiu adalah suatu aktivitas yang sangat berbahaya jika dilakukan. Hal ini dikarenakan mindset setiap orang dapat dikatakan memiliki pemikiran yang sama yaitu menganggap bahwa ikan hiu adalah seekor hewan predator yang akan memangsa apa saja yang ada didekatnya termasuk manusia. Meskipun begitu membahayakan, beberapa orang menyukai tantangan ini dan terus melakukannya, tetapi dengan memperhatikan keselamatan diri sendiri. Ada proses terapi yang dipandu dengan instruktur sebelum melakukan penyelaman. Proses tersebut merupakan bagian dari langkah-langkah wisatawan dalam melakukan aktivitas wisata berenang bersama ikan hiu (swim with shark).

Adapun langkah-langkah aktivitas wisata berenang bersama ikan hiu yang diterapkan pihak perusahaan dan wajib untuk dilakukan oleh wisatawan adalah sebagai berikut:

a. Wisatawan memastikan bahwa telah mengenakan peralatan keamanan diri dengan baik dan benar dengan diberi arahan dari instruktur.

b. Wisatawan yang sudah siap, kemudian menggunakan speed boat sebagai sarana transportasi dari pesisir menuju keramba di tengah laut, tempat dimana beradanya ikan hiu sirip putih. Waktu yang ditempuh sekitar 5 menit hingga menuju kolam ikan hiu.

c. Sesampainya disana, wisatawan terlebih dahulu memberi makan ikan hiu sampai 
merasa kenyang dan tidak ingin makan lagi. Proses ini dinamakan Shark Feeding.

d. Bagi wisatawan pemula, wajib melakukan latihan penyelaman terlebih dahulu di keramba kecil, dimana terdapat ikan hiu sirip putih yang masih kecil. Panjang ikan hiu anak kira-kira mencapai $15-20 \mathrm{~cm}$. Hal ini dilakukan beberapa saat agar wisatawan belajar untuk beradaptasi dengan ikan hiu sirip putih yang masih kecil dan hingga keberanianya teruji. Dengan tujuan meyakinkan wisatawan agar tidak merasa takut dengan ikan hiu, bahwasanya ikan hiu jenis white tip dapat diajak bermain dan berenang bersama.

e. Kemudian wisatawan dapat menyelam pada keramba yang besar yang didalamnya juga terdapat ikan hiu yang sedang dan agak besar. Panjang ikan hiu pada keramba besar rata-rata mencapai kisaran 1,5 meter hingga 2 meter. Aktivitas yang dapat dilakukan selama penyelaman adalah wisatawan dapat menyentuh ikan hiu dengan lembut dan juga berfoto bersama ikan hiu. Ikan hiu yang sudah jinak dengan sendirinya akan menghampiri wisatawan dan bermain bersama.

f. Durasi yang berlaku bagi wisatawan pada saat melakukan aktivitas wisata berenang dengan ikan hiu adalah kira-kira 30-60 menit. Namun bagi wisatawan yang ingin berlama-lama juga ada tambahan waktu 30 menit sehingga maksimal waktu yang diberikan adalah 90 menit.

g. Pada saat waktu yang bersamaan hanya diperbolehkan maksimal 5 orang wisatawan termasuk instuktur yang melakukan aktivitas wisata berenang bersama ikan hiu dalam 1 keramba. Hal ini dilakukan agar mencegah keramaian pada suatu kolam yang mengakibatkan kecelekaan pada wisatawan ataupun nelayan.

h. Setelah selesai wisatawan berkemas dan diantarkan kembali ke restoran Gold Island untuk melanjutkan aktivitas paket lainnya.

\section{b. Penerapan K3 pada aktivitas wisata berenang dengan ikan hiu (Swim With Shark)}

Faktor-faktor yang mempengaruhi terjadinya kecelakaan umumnya kecelakaan yang biasa terjadi diakibatkan oleh 2 Faktor yaitu internal (manusia) dan eksternal (lingkungan atau makhluk lain selain dirinya sendiri). Faktor tersebut diantaranya:

\section{Faktor Internal:}

a. Faktor usia. Usia yang sudah lanjut mengakibatkan seorang karyawan ataupun wisatawan tidak dapat lagi beraktivitas lebih dari biasanya. Hal ini biasa berkaitan dengan stamina dan waktu lamanya bekerja seorang nelayan sehingga mudah lelah. Dalam aktivitas ini, karyawan yang lelah tidak diperbolehkan untuk mengantarkan tamu, atau wisatawan tidak boleh terlalu lama berada dalam kolam penangkaran ikan hiu, karena besar resiko yang ditimbulkan jika lalai sedikit saja.

b. Faktor penyakit. Wisatawan ataupun karyawan yang memiliki penyakit secara fisik misalkan mengeluarkan darah akibat luka-luka ataupun datang bulan menarik perhatian ikan hiu untuk dimangsa, karena ikan hiu sangat sensitive dengan bau amis seperti darah. Selain penyakit fisik juga penyakit cacat mental. Jika ada diantara karyawan ataupun wisatawan yang akan melakukan aktivitas ini tentunya tidak diperbolehkan. Karena orang yang memiliki cacat mental lebih agresif dalam tingkah laku dan tindakan yang tidak dapat dikontrol pada saat beraktivitas, akan menggangu konsentrasi pawang atau membuat pergerakan hiu menjadi liar. Hal ini yang mengakibatkan resiko terjadinya kecelakaan di lapangan.

c. Tidak menggunakan peralatan safety seperti Life jacket maupun peralatan snorkling lainnya. Atau menggunakan warna pakaian yang mencolok yang membuat ikan hiu mengira bahwa warna pakaian tersebut adalah mangsanya.

d. Tidak mendengarkan atau mengikuti arahan instruktur dengan benar pada saat melakukan aktivitas wisata ekstrim berenang dengan ikan hiu. Atau melakukan hal-hal diluar dari arahan yang diberikan seperti terlalu berani, sembrono, tidak mau bekerja sama, kelalaian melamun, dan kurang sabar.

\section{Faktor Eksternal:}

Faktor Lingkungan. Dalam aktivitas wisata berenang bersama ikan hiu (swim with shark) ada juga beberapa faktor lingkungan yang memicu resiko terjadinya kecelakaan seperti: cuaca yang semakin panas membuat pergerakan ikan hiu menjadi lebih agresif dan 
cukup liar. Gelombang yang cukup besar serta keruhnya air membuat penglihatan dan konsentrasi ikan hiu menjadi lemah sehingga bisa juga mengakibatkan ikan hiu tersebut menjadi liar. Hujan lebat yang berkepanjangan juga menimbulkan resiko bagi wisatawan dalam beraktivitas maupun penglihatan ketika berada dalam kolam penangkaran ikan hiu. Apabila situasi cuaca dan air memburuk maka wisatawan tidak diperbolehkan untuk melakukan aktivitas wisata berenang bersama ikan hiu.

\section{Penerapan K3 pada karyawan}

Adapun penerapan K3 yang dilakukan pihak perusahaan restoran Gold Island terhadap karyawannya dalam hal ini adalah nelayan sebagai guide dan intrusktur wisatawan adalah dengan menerapkan syarat demi keselamatan karyawan itu sendiri. Syarat tersebut diantaranya sebagai berikut:

a. Pihak perusahaan memastikan semua karyawan yang bekerja sebagai nelayan (guide atau instruktur) harus dalam kondisi sehat, atau tidak memiliki penyakit baik cacat fisik maupun cacat mental.

b. Para nelayan harus ahli dalam bidangnya seperti menangkap ikan atau bisa menyelam, serta mengetahui kondisi cuaca yang terjadi di laut.

c. Para nelayan dibekali pengetahuan tentang ikan hiu sirip putih dan siklus hidupnya, sehingga nelayan dapat mempelajari kehidupan ikan hiu sirip putih pada saat ikan tersebut tenang atau liar.

d. Para nelayan di beri pelatihan kurang lebih enam bulan untuk beradaptasi dengan ikan hiu yang didampingi oleh nelayan yang lebih dulu berkecimpung didalam bidang ini. Pelatihan tersebut yaitu setiap hari para nelayan harus berenang bersama ikan hiu dan memberinya makan. Dengan begitu ikan hiu akan lebih mudah berinteraksi dengan manusia.

e. Perusahaan juga memberikan asuransi bagi setiap karyawan yang bekerja di perusahaannya seperti restoran Gold Island, water sport, dan swim with shark.

f. Setiap karyawan atau nelayan yang akan melakukan aktivitas wisata berenang bersama ikan hiu (swim with shark) harus menggunakan peralatan pengamanan (safety) seperti life jacket dan peralatan snorkeling atau menyelam lainnya.

Meskipun para karyawan atau nelayan terkhususnya yang bekerja pada aktivitas wisata berenang bersama ikan hiu (swim with shark), sudah ahli dalam bidangnya tentu saja tetap perlu memperhatikan langkah-langkah keselamatan dan kesehatan kerjanya. Hal ini dikarenakan aktivitas wisata yang dilakukan masih bersifat wisata ekstrim yang dapat membahayakan nyawa seseorang.

\section{Penerapan K3 pada wisatawan}

Penerapan K3 yang dilakukan nelayan kepada wisatawan yaitu dengan memberlakukan syarat bagi seorang wisatawan, dan memberikan intruktur dari nelayan. Wisatawan sebelum melakukan penyelaman di beri arahan (briefing) terlebih dahulu terkait dengan aktivitas yangakan dilakukan dan larangan yang tidak boleh dilanggar.

1. Syarat:

a. Usia yang diperkenankan untuk melakukan aktivitas wisata ekstrim ini dimulai dari $10-60$ tahun. Usia ini ditetapkan karena pada usia dini dibawah 10 tahun, biasanya anak-anak atau seorang remaja rentan melakukan gerakangerakan yang hyper aktif sehingga tidak dapat terkontrol akan memicu stresnya seekor hiu, sehingga mengakibatkan hiu tersebut lepas kendali dan dapat menyerang wisatawan. Sedangkan bagi usia lanjut diatas 60 tahun, pergerakannya justru sebaliknya, semakin melambat. Apabila terjadi sesuatu yang tidak diduga maka sulit bagi para usia lanjut untuk menyelamatkan diri. Kecuali diluar dari usia tersebut ada wisatawan yang memang menyanggupi aktivitas tersebut dengan memperhatikan resiko yang akan ditimbulkan.

b. Seorang wisatawan yang melakukan aktivitas wisata berenang dengan ikan hiu tidak memiliki penyakit apapun. Dianjurkan bagi wisatawan yang sedang mengalami penyakit fisik (misalnya luka, datang bulan) atau cacat fisik maupun mental, agar tidak melanjutkan aktivitas wisata berenang dengan hiu. Apabila ada diantara wisatawan yang memiliki penyakit, maka yang bersangkutan tidak diperbolehkan melakukan aktivitas swim with 
shark. Dengan kata lain wisatawan harus benar-benar dalam keadaan sehat.

c. Wisatawan tidak boleh melakukan hal-hal diluar dari pada arahan nelayan ataupun instruktur lainnya.

d. Wisatawan wajib mengenakan peralatan pengamanan diri, seperti baju selam, alat snorkeling dan life jaket. Jika tidak ingin menggunakan baju selam dapat menggunakan baju biasa dengan warna baju yang tidak mencolok. Dikarenakan ikan hiu akan merasa asing apabila ada warna mencolok lainnya yang masuk kedalam kolam dan bisa langsung diserang sebab ikan hiu mengira wisatawan adalah mangsanya.

\section{Instruktur (Arahan)}

Beberapa arahan yang diberikan nelayan kepada wisatawan yang akan melakukan aktivitas wisata berenang bersama ikan hiu (swim with shark) adalah:

a. Mengkonfirmasi kembali wisatawan terlebih dahulu bahwa wisatawan tersebut benar-benar ingin melakukan aktivitas wisata berenang bersama ikan hiu (Swim With Shark).

$b$. Menyuguhkan tontonan video tutorial bagi wisatawan dalam memberi makan ikan hiu maupun menyelam bersama ikan hiu.

c. Bagi wisatawan yang sedang mengalami sakit dan tidak melakukan aktivitas wisata berenang dengan ikan hiu, hanya dapat melihat ikan hiu dari atas keramba dan memberi makan saja. Hal ini dilakukan agar mengantisipasi terjadinya kecelakaan yang dapat merugikan berbagai pihak.

d. Gunakan Life Jacket atau pelampung dan peralatan snorkeling dengan baik ketika sudah memasuki kolam ikan hiu, atau pada saat menuju keramba dengan menggunakan speed boat.

e. Bila ingin menyelam Anda dapat menggunakan peralatan menyelam seperti pada perlatan snorkeling biasanya. Tidak menggunakan tabung gas dan lain-lain karena kolam tersebut tidak sedalam lautan lepas hanya berada pada kedalaman sekitar 2-3 meter saja dari permukaan laut.

f. Pada saat melakukan penyelaman wisatawan tidak boleh menarik ikan hiu atau pada ekornya karena akan memicu stresnya ikan hiu dan menjadi liar yang berakibat pada kecelakaan. g. Pada saat memberi makan ikan hiu, tidak boleh ada wisatawan yang melakukan penyelaman atau berada dalam kolam ikan hiu, karena ikan hiu akan mengira bahwa manusia juga bagian dari makanannya.

$h$. Wisatawan pada saat melakukan penyelaman harus tetap tenang dan jangan panik.

$i$. Jika cuaca buruk maka aktivitas wisata berenang bersama ikan hiu (swim with shark) tidak diperkenankan.

j. Apabila air dikolam ikan hiu keruh sebaiknya wisatawan menggunakan kacamata renang dengan baik dan benar sehingga tidak menimbulkan iritasi pada mata.

\section{SIMPULAN DAN SARAN}

\subsection{Simpulan}

Aktivitas wisata berenang bersama ikan hiu (swim with shark) di Pulau Serangan merupakan jenis wisata ekstrim yang cukup aman dilakukan. Hal ini ditinjau dari berbagai aspek antara lain :

1. Aktivitas wisata yang dilakukan wisatawan tergolong cukup aman karena aktivitas yang dilakukan wisatawan adalah memberi makan ikan hiu, menyelam bersama dengan ikan hiu, menyentuh atau berinteraksi fisik dengan ikan hiu dan juga berfoto bersama. Jenis ikan hiu yang dijadikan sebagai daya tarik wisata adalah jenis ikan hiu sirip putih yang tergolong cukup aman karena tidak menyerang manusia dan jenis makanannya berupa ikan kecil.

2. Upaya Penerapan K3 yang dilakukan oleh pihak perusahaan sudah cukup baik yakni memberlakukan syarat dan arahan kepada wisatawan dan karyawan yang akan melakukan aktivitas berenang bersama ikan hiu (swim with shark). Agar meminimalisir terjadinya resiko kecelakaan. Syarat dan arahan yang diberikan yaitu tidak boleh adanya penyakit apapun bagi wisatawan ataupun karyawan baik itu penyakit fisik atau mental, seperti luka-luka, darah yang memicu terjadinya kecelakaan. Selain itu bentuk pencegahan dan penanggulangan kecelakaan yang disediakan pihak Perusahaan seperti memberikan jaminan asuransi Jasindo dan menyediakan kotak P3K kepada wisatawan sewaktu-waktu diperlukan pada saat terjadinya kecelakaan. 


\subsection{Saran}

Adapun Saran yang dapat diberikan yaitu sebagai berikut:

1. Pihak perusaahan perlu menyediakan tim medis yang ahli dibidangnya. Sehingga dalam penanganannya, korban dapat tertolong dengan cepat pada saat terjadi kecelakaan tanpa harus menunggu lama menuju ke rumah sakit terdekat.

2. Perlu adanya pelatihan terus menerus bagi karyawan terkait dengan aktivitas ini, agar karyawan benar-benar memahami kehidupan ikan hiu.

3. Penerapan K3 pada aktivitas wisata berenang bersama ikan hiu (swim with shark) harus dengan menggunakan Standar Operasional Prosedur K3 yang benar misalnya, penyediaan Kotak P3K sebaiknya sesuai dengan standar isi Kotak P3K Nasional. Sehingga dengan adanya kelengkapan tersebut, pertolongan pertama yang diberikan pada korban sewaktu terjadinya kecelakaan dipermudah.

4. Perlu adanya penelitian lanjutan terkait dengan peran guide maupun pengelola dalam menanggulangi dan mencegah berbagai dampak yang ditimbulkan akibat kecelakaan insiden lainnya yang terjadi dilapangan, sehingga dapat meningkatkan kesigapan atau mengantisipasi hal-hal yang tidak diinginkan.

\section{DAFTAR PUSTAKA}

Damardjati, R.S. 2003. Istilah-istilah Dunia pariwisata, Jakarta: Pradnya Paramitha

Moleong, Lexi. 2012. Metodologi Penelitian Kualitatif. Bandung: PT. Renaja Rosdakarya

Sucipto, Cecep Dani. 2014. Keselamatan dan Kesehatan Kerja. Yogyakarta: Gosyen Publishing.

Sudiana,I Gusti Ngurah. Transformasi Budaya Masyarakat Desa Serangan di Denpasar Selatan Dalam Pelestarian Satwa Penyu. Denpasar.(Jurnal)

Sugiyono. 2014. Metode Penelitian Kuantitatif Kualitatif dan R\&D. Bandung: Penerbit Alfabeta.

UU pemerintah, No. 1 Tahun 1970 Pasal 3 Ayat 1 tentang keselamatan Kerja

Vityala, Intifadah. 2014. Penerapan Kesehatan dan Keselamatan Kerja di Benoa Tirta Harum Dive and Watersport.Denpasar. (Jurnal)
WTO, 2003.Tuntutan Keselamatan dan Keamanan Wisatawan. Jakarta: PT. Pradaya Paramita 